\title{
ASAS DAN NORMA HUKUM ADMINISTRASI NEGARA DALAM PEMBUATAN INSTRUMEN PEMERINTAHAN
}

\author{
Tubagus Muhammad Nasarudin \\ Universitas Malahayati Bandar Lampung \\ Dosen Hukum Tata Negara dan Hukum Administrasi Negara \\ Email: tbnasarudin@gmail.com
}

\begin{abstract}
ABSTRAK
Ketika membahas Indonesia sebagai negara hukum, maka turut pula mengkaji tugas-tugas administrasi pemerintahan dan negara, baik secara aturan hukum tertulis dalam konstitusi atau aturan yang terkumpul di hukum konstitusi. Namun demikian, untuk pelaksanaan isu-isu yang bersifat teknis, hukum konstitusi belum sepenuhnya dilaksanakan secara efektif. Mengingat negara adalah organisasi kekuasaan, maka Hukum Administrasi Negara (HAN) dibutuhkan sebagai instrumen untuk memantau penggunaan kekuasaan pemerintahan. Kajian ini mengakomodir dua permasalahan, yaitu batasan definitif dari peraturan perundang-undangan, kebijakan, dan keputusan menurut HAN dan asas-asas dan norma-norma HAN dalam pembuatan peraturan perundang-undangan, peraturan kebijakan, dan keputusan. Penelitian ini dilakukan dengan pendekatan hukum normatif atau studi pustaka hukum. Hasil studi ini menyatakan bahwa Peraturan adalah hukum yang in abstracto atau general norm yang sifatnya mengikat umum (berlaku umum) dan tugasnya adalah mengatur hal-hal yang bersifat umum (general). Sementara Peraturan kebijakan hanya berfungsi sebagai bagian dari operasional penyelenggaraan tugas-tugas pemerintahan, karenanya tidak dapat mengubah ataupun menyimpangi peraturan perundang-undangan. Akhirnya, klausul pengaman (veiligheidsclausule) pada suatu keputusan dapat disimpulkan sebagai hal yang tidak bermanfaat dan mubazir, sebab dapat menggoyahkan sendi-sendi kepastian hukum. Karena rumusan seperti ini, di satu sisi bertentangan dengan asas kepastian hukum dan di sisi lain bertentangan dengan asas praduga rechtmatig.
\end{abstract}

Kata kunci: Asas dan Norma Hukum, Hukum Adiministrasi Negara, Instrumen Pemerintahan

\section{ABSTRACT}

When discussing Indonesia as a rule of law, it also contributes to review the government and state administrative duties, either the rule of law that is written in the constitution or the rule of law that is collected by the constitutional law. However, to administer the technical issues, the constitutional law is not implemented effectively. Considering the state as the organization of power, the administrative law (HAN) is needed as the instrument to observe the use of the government power. This study accommodates two issues: the definitive limitation of the legislation, policy-making, and decision according to the Administrative Law; Administrative Law principles and norms in legislation, and policy-making and decision. This study uses a normative law approach or a law literature. The result of this study states that the regulation is an in abstrac to law or a general norm that binds and regulates general cases. Besides, the 
policy law is only functioned as a part of the organization operational of the government duties. Hence it can not change or deviate the legislation. Finally, the safety clause (veiligheidsclausule) will be useless and redundant for it can tremble the legal certainty. In one hand, this kind of formula contradicts with the principles of legal certainty and contradicts to the rechtmatig presumption.

Keywords: Principles and norms of law, Administrative law (HAN), government instrument

\section{A. LATAR BELAKANG}

Gagasan negara hukum pertama kali dikemukakan oleh Plato, ketika ia menulis Nomoi, sebagai karya tulis ketiga yang dibuat di usia tuanya.Sementara dalam dua tulisan pertama, Politeia dan Politicos, belum muncul istilah negara hukum. Plato mengemukakan dalam Nomoi, bahwa penyelenggaraan negara yang baik ialah yang didasarkan pada pengaturan (hukum) yang baik. Gagasan Plato tentang negara hukum ini semakin tegas ketika didukung oleh muridnya, Aristoteles, suatu negara yang baik adalah negara yang diperintah dengan konstitusi dan berkedaulatan hukum (Ridwan HR, 2011: 2).

Gagasan negara hukum tersebut masih bersifat samar-samar dan tenggelam dalam waktu yang sangat panjang, kemudian muncul kembali secara lebih eksplisit pada abad ke-19, yaitu dengan munculnya konsep rechtsstaat dari Freidrich Julius Stahl, yang diilhami oleh pemikiran Immanuel Kant. Menurut Stahl, unsur-unsur negara hukum (rechtsstaat) adalah sebagai berikut (Ridwan HR, 2011: 2):

1. Perlindungan hak-hak asasi manusia

2. Pemisahan atau pembagian kekuasaan untuk menjamin hak-hak itu

3. Pemerintahan berdasarkan peraturan perundang-undangan, dan

4. Peradilan administrasi dalam perselisihan.

Pada wilayah Anglosaxon, muncul pula konsep-konsep negara hukum (rule of law) dari A.V. Dicey, dengan unsur-unsur sebagai berikut (Ridwan HR, 2011: 2):

1. Supremasi aturan-aturan hukum (supemacy of the law); tidak adanya kekuasaan sewenang-wenang (absence of the law);

2. Kedudukan yang sama dalam menghadapi hukum (equality before the law). Dalil ini berlaku, baik untuk orang biasa maupun pejabat; dan

3. Terjaminnya hak-hak manusia oleh undang-undang serta keputusankeputusan pengadilan.

Pada perkembangannya, konsepsi negara hukum tersebut kemudian mengalami penyempurnaan yang secara umum dapat dilihat unsur-unsurnya sebagai berikut (Ridwan HR, 2011: 4-5):

1. Sistem pemerintahan negara yang didasarkan atas kedaulatan rakyat.

2. Bahwa pemerintah dalam melaksanakan tugas dan kewajibannya harus berdasar atas hukum atau peraturan perundang-undangan.

3. Adanya jaminan terhadap hak-hak asasi manusia (warga negara).

4. Adanya pembagian kekuasaan dalam negara. 
5. Adanya pengawasan dari badan-badan peradilan (rechterlijke controle) yang bebas dan mandiri, dalam arti lembaga peradilan tersebut benar-benar tidak memihak dan tidak berada di bawah pengaruh eksekutif.

6. Adanya peran yang nyata dari anggota-anggota masyarakat atau warga negara untuk turut serta mengawasi perbuatan dan pelaksanaan kebijaksanaan yang dilakukan oleh pemerintah.

7. Adanya sistem perekonomian yang dapat menjamin pembagian yang merata sumber daya yang diperlukan bagi kemakmuran warga negara.

Berdasarkan ketentuan Pasal 1 ayat (3) UUD NRI 1945, "Negara Indonesia adalah negara hukum" yang menganut desentralisasi dalam penyelenggaraan pemerintahan, sebagaimana diisyaratkan dalam Pasal 18 ayat (1) UUD NRI 1945 "Negara Kesatuan Republik Indonesia dibagi atas daerah-daerah provinsi, kabupaten, dan kota mempunyai pemerintah daerah, yang diatur dengan undangundang". Sebagai negara hukum, setiap penyelenggaraan urusan pemerintahan haruslah berdasarkan pada hukum yang berlaku (wetmatigheid van bestuur). Sebagai negara yang menganut desentralisasi mengandung arti bahwa urusan pemerintahan itu terdiri atas urusan pemerintahan pusat dan urusan pemerintahan daerah. Artinya ada perangkat pemerintah pusat dan ada perangkat pemerintah daerah yang diberi otonomi yakni kebebasan dan kemandirian untuk mengatur urusan rumah tangga daerah (Ridwan HR, 2011: 17).

Merujuk pada rumusan tujuan negara yang tercantum dalam alenia keempat Pembukaan UUD 1945 khususnya pada redaksi "memajukan kesejahteraan umum", ada yang berpendapat bahwa Indonesia menganut paham negara kesejahteraan (welfare state), seperti Azhary dan Hamid S. Attamimi. Menurut Hamid S. Attamimi, bahwa negara Indonesia memang sejak didirikan bertekad menetapkan dirinya sebagai negara yang berdasar atas hukum, sebagai rechtsstaat. Bahkan rechtsstaat Indonesia itu ialah rechtsstaat yang memajukan kesejahteraan umum, mencerdaskan kehidupan bangsa, dan mewujudkan suatu keadilan sosial bagi seluruh rakyat Indonesia (Ridwan HR, 2011: 18).

Menurut Philipus M. Hadjon, ide rechtsstaat cenderung ke arah positivisme hukum yang membawa konsekuensi bahwa hukum harus dibentuk secara sadar oleh badan pembentuk undang-undang. Sebagai negara hukum, hukum ditempatkan sebagai aturan main dalam penyelenggaraan kenegaraan, pemerintahan, dan kemasyarakatan, sementara tujuan hukum itu sendiri antara lain "...opgelegd om de samenleving vreedzaam, rechtvaardig, en doelmatig te ordenen" (diletakkan untuk menata masyarakat yang damai, adil, dan bermakna) (Ridwan HR, 2011: 21).

Penyelenggaraan tugas-tugas pemerintahan dan kenegaraan dalam suatu negara hukum itu memiliki aturan-aturan hukum yang tertulis dalam konstitusi atau peraturan-peraturan yang terhimpun dalam hukum tata negara. Meskipun demikian, untuk penyelenggaraan persoalan-persoalan yang bersifat teknis, hukum tata negara ini tidak sepenuhnya dapat dilaksanakan dengan efektif. Artinya, hukum tata negara membutuhkan hukum lain yang bersifat teknis. Hukum tersebut adalah Hukum Administrasi Negara (HAN). Mengingat negara itu merupaka organisasi 
kekuasaan (machtenorganisatie), maka pada akhirnya hukum administrasi negara akan muncul sebagai instrumen untuk mengawasi penggunaan kekuasaan pemerintahan. Oleh karenanya, keberadaan HAN muncul karena adanya penyelenggaraan kekuasaan negara dan pemerintahan dalam suatu negara hukum, yang menuntut dan menghendaki penyelenggaraan tugas-tugas kenegaraan, pemerintahan, dan kemasyarakatan yang berdasarkan atas hukum. Menurut Philipus M. Hadjon, ukuran atau indikasi negara hukum adalah berfungsinya hukum administrasi, sebaliknya suatu negara bukanlah negara hukum secara realitas apabila hukum administrasi tidak berfungsi (Ridwan HR, 2011: 23).

Dari uraian di atas, muncul beberapa permasalahan yang dapat dirumuskan, yaitu:

1. Apa pengertian dari peraturan perundangan-undangan, kebijakan, dan keputusan menurut hukum administrasi negara?

2. Bagaimana asas-asas dan norma-norma hukum administrasi negara dalam pembuatan peraturan perundan-undangan, peraturan kebijakan, dan keputusan?

\section{B. PEMBAHASAN}

1. Definisi Peraturan Perundangan-Undangan, Kebijakan, dan Keputusan Menurut Hukum Adiministrasi Negara

\section{a. Peraturan Perundang-Undangan}

Peraturan merupakan hukum yang in abstracto atau general norms yang sifatnya mengikat umum (berlaku umum) dan tugasnya adalah mengatur hal-hal yang bersifat umum (general) (Marbun dan Mahfud MD, 2006: 94).

Menurut Penjelasan Pasal 1 angka 2 UU No. 5 Tahun 1986 tentang Peradilan Tata Usaha Negara, peraturan perundang-undangan adalah semua peraturan yang bersifat mengikat secara umum yang dikeluarkan oleh Badan Perwakilan Rakyat bersama pemerintah, baik di tingkat pusat maupun di tingkat daerah yang juga mengikat secara umum. Rumusan pengertian peraturan perundang-undangan seperti demikian ini mencakup pengertian materiil dan formil (Marbun, 2011: 182).

Berdasarkan rumusan penjelasan Pasal 1 angka 2, UU No. 5 Tahun 1986 tersebut, dapat disimpulkan bahwa keputusan dari badan atau pejabat tata usaha negara yang merupakan pengaturan yang bersifat umum (besluit van algemene strekking) termasuk peraturan perundang-undangan (algemeen verbindende voorschriften) (Hadjon, 1999: 151).

Menurut seorang sarjana Jerman, Paul Laband, undang-undang dapat diartikan secara formil dan secara materiil (wet in formele zin dan wet in materiele zin). Undang-undang dalam arti formil (wet in formele zin) adalah setiap peraturan (keputusan pemerintah) yang dikaitkan dengan cara terjadinya atau cara pembentukannya. Sementara di Indonesia, pengertian Undang-Undang dalam arti formil adalah setiap produk hukum yang dibuat oleh Presiden bersama Dewan Perwakilan Rakyat (DPR). Sedangkan Undang-Undang dalam arti materiil adalah suatu penetapan kaidah hukum dengan tegas sehingga kaidah hukum itu 
mempunyai sifat mengikat. Menurut Paul Laband sifat mengikatnya suatu aturan hukum harus memerlukan dua unsur, yakni penetapan secara tegas (anordnung) dan peraturan atau isi hukumnya itu sendiri (rechtsstaat). Menurut Buys dalam bukunya De Grond wet, Toelichting en Kritiek (1883), mengemukakan bahwa yang dimaksud undang-undang dalam arti materiil adalah setiap keputusan pemerintah (overheid) yang isinya mengikat langsung pada setiap penduduk (Marbun, 2011:182).

Berkenaan dengan perundang-undangan, A. Hamid S. Attamimi menulis sebagai berikut (Attamimi, 1992:3):

"istilah perundang-undangan (wettelijkeregels) secara harfiah dapat diartikan peraturan yang berkaitan dengan undang-undang, baik peraturan itu berupa undang-undang sendiri maupun peraturan lebih rendah yang merupakan atribusian ataupun delegasian undang-undang. Atas dasar atribusi dan delegasi kewenangan perundang-undangan maka yang tergolong peraturan perundang-undangan di negara kita adalah undang-undang dan peraturan perundang-undangan yang lebih rendah daripadanya seperi peraturan pemerintah, keputusan presiden yang berisi peraturan, keputusan menteri yang berisi peraturan, keputusan kepala lembaga pemerintah nondepartemen yang berisi peraturan, keputusan direktur jenderal departemen yang berbentuk dengan undang-undang yang berisi peraturan, peraturan daerah tingkat 1 , keputusan gubernur kepala daerah berisi peraturan yang melaksanakan ketentuan peraturan daerah tingkat 1, peraturan daerah tingkat II, dan keputusan bupati/walikota kepala daerah berisi peraturan yang melaksanakan ketentuan peraturan daerah tingkat II".

Peraturan perundang-undangan memiliki ciri-ciri sebagai berikut (Ridwan HR, 2011: 130):

1) Bersifat umum dan komprehensif, yang dengan demikian merupakan kebalikan dari sifat-sifat yang khusus dan terbatas.

2) Bersifat universal. Ia diciptakan untuk menghadapi peristiwa-peristiwa yang akan datang yang belum jelas bentuk konkretnya. Oleh karena itu, ia tidak dapat dirumuskan untuk mengatasi peristiwa-peristiwa tertentu saja.

3) Ia memiliki kekuatan untuk mengoreksi dan memperbaiki dirinya sendiri. Adalah lazim bagi suatu peraturan untuk mencantumkan klausul yang memuat kemungkinan dilakukannya peninjauan kembali.

Menurut Pasal 1 angka 2 UU No. 10 Tahun 2004 Tentang Pembentukan Peraturan Perundang-undangan, yang dimaksud dengan peraturan perundangundangan adalah peraturan tertulis yang dibentuk oleh lembaga negara atau pejabat yang berwenang dan mengikat secara umum. Peraturan perundang-undangan yang bersifat mengikat umum (algemeen verbindend voorschrift) disebut juga dengan istilah undang-undang dalam arti materiil (wet in materiele zin), yaitu ieder rechtsvoorschrift van de overheid met algemeen strekking (semua hukum tertulis dari pemerintah yang mengikat umum). Berdasarkan kualifikasi norma hukum di atas, 
peraturan perundang-undangan itu bersifat umum-abstrak. Perkataan bersifat umum-abstrak dicirikan oleh unsur-unsur sebagai berikut(Ridwan HR, 2011: 131132):

1) Tijd (een regel geldt niet slechts op een moment); Waktu (tidak hanya berlaku pada saat tertentu);

2) Plaats (een regel geldt niet slecht op een plaats); Tempat (tidak hanya berlaku pada tempat tertentu);

3) Persoon (een regel geldt niet slechts voor bepaalde persoon); Orang (tidak hanya berlaku pada orang tertentu); dan

4) Rechtsfeit (een regel geldt niet voor een enkel rechtsfeit, maar voor rechtsfeitendie herhaalbaar zijn, dat wil zeggen zich telkens voor kunnen doen). Fakta hukum (tidak hanya ditujukan pada hukum tertentu, tetapi untuk berbagai fakta hukum yang dapat berulang-ulang, dengan kata lain untuk perbuatan yang berulang-ulang).

\section{b. Kebijakan}

Kebijaksanaan atau Freies Ermessen dalam bahasa Jerman berasal dari kata frei yang berarti bebas, merdeka, tidak terikat. Kata freis berarti orang bebas, sedangkan kata ermessen berarti mempertimbangkan, menilai, menduga, penilaian, pertimbangan atau keputusan. Bahasa Inggris menyebutnyadiscretion yang berarti kebijaksanaan, keleluasaan, kehati-hatian, atau discretionnaire (kata sifat), yang berarti menyerahkan kepada kebijaksanaan dengan kebebasan untuk menentukan atau memilih (Marbun, 2011: 186-187).

Stanley De Smith and Rodney Brazier,mengartikan diskresi/freies Ermessen sebagai "... power to choose between alternative courses of action ...", sedangkan H.W.R. Wade, menyebutkan sebuah prinsip utama dari diskresi/freies Ermessen adalah "... the rule that the participation of non-membersin the deliberation or decision of a collective body may in validate its acts..." (Smith and Rodney, 1986: 571).Sementara itu, Amrah Muslimin,mengartikan fries ermessen sebagai “...lapangan bergerak selaku kebijaksanaan atau kebebasan kebijaksanaan..." (Muslimin, 1985: 73).

Berbeda dengan Hans J. Wolf dalam bukunya Verwaltungsrecht I, sebagaimana dikutip oleh Marcus Luqman, ia menyatakan bahwa freies Ermessen tidak boleh diartikan secara berlebihan, seakan-akan badan atau pejabat administrasi negara boleh bertindak sewenang-wenang atau tanpa dasar atau dengan dasar yang tidak jelas ataupun dengan pertimbangan yang subjektif-individual. Karena itu menurut Hans J. Wolf lebih baik dikatakan mereka bertindak berdasarkan kebijaksanaan(Lukman, 1989: 145).

Jika freies Ermessen dilihat dari kerangka sistem regim administrasi di Jerman, maka freies Ermessen merupakan sarana yang memberikan ruang gerak bagi administrasi negara untuk mengambil tindakan yang tidak terikat sepenuhnya pada undang-undang. Sedangkan dalam sistem ketatanegaraan Inggris, menurut A.V. Dicey, sebagaimana dikutip oleh Bagir Manan, “...discretionary power itu berisi kebebasan mahkota atau aparatnya untuk melakukan persetujuan atau pengaturan 
oleh parlemen. Jadi discretionary bersumber pada prerogratif dan tidak pada undang-undang..." (Marbun, 2011: 188).

Sjachrab Basah, memberikan pengertian freies Ermessen sebagai keleluasaan dalam menentukan kebijakan-kebijakan melalui sikap tindak administrasi negara yang harus dapat dipertanggungjawabkan. Dengan demikian freies Ermessen adalah kebebasan untuk bertindak atas inisiatif sendiri menyelesaikan persoalan-persoalan penting dan mendesak yang muncul secara tiba-tiba, dimana hukum tidak mengaturnya, serta harus dapat dipertanggungjawabkan baik secara hukum maupun moral (Marbun, 2011: 188).

\section{c. Keputusan}

Keputusan merupakan salah satu objek studi penting dalam hukum administrasi, utamanya karena keputusan merupakan objek sengketa yang menjadi kompetensi absolut peradilan administrasi menurut UU No. 5 Tahun 1986. Kecuali itu keputusan merupakan salah satu instrumen yuridis pemerintahan yang banyak digunakan oleh pemerintah dalam melakukan tindakan-tindakannya untuk menyatakan kehendaknya (Marbun, 2011: 147).

Istilah keputusan merupakan terjemahan dari istilah beschikking yang berasal dari bahasa Belanda, sedangkan dalam bahasa Perancis disebut istilah acte administratif, dan dalambahasa Jerman disebut verwaltungsakt (Marbun, 2011: 148). Istilah beschikkingdi Indonesia diperkenalkan pertama kali oleh WF. Prins. yang berarti ketetapan (Ridwan HR, 2011, 140). Djenal Hoesen mengatakan bahwa penggunaan istilah keputusan barangkali akan lebih tepat untuk menghindari kesimpangsiuran pengertian dengan istilah ketetapan. Menurutnya, di Indonesia, istilah ketetapan sudah memiliki pengertian teknis yuridis, yaitu sebagai ketetapan MPR yang berlaku ke luar dan ke dalam (Koesoemahatmadja, 1979: 47).

Beberapa sarjana yang memberikan definisi beschikking, antara lain (Marbun, 2011: 148):

1) Mr. Drs. E. Utrecht dalam bukunya Pengantar Hukum Tata Usaha Indonesia, menyatakan beschikking (ketetapan) adalah suatu perbuatan hukum publik yang bersegi satu yang dilakukan oleh alat-alat pemerintahan berdasarkan suatu kekuasaan istimewa.

2) Mr. WF. Prins dalam bukunya Inleiding in het Administratiefrecht van Indonesia, menyebutkan beschikking sebagai suatu tindakan hukum sepihak dalam lapangan pemerintahan yang dilakukan oleh alat pemerintahan berdasarkan wewenang yang ada pada alat atau organ itu.

3) Van der Pot dalam bukunya Nederlandsch Bestuursrecht menyatakan beschikking adalah perbuatan hukum yang dilakukan alat-alat pemerintahan, pernyataan-pernyataan kehendak alat-alat pemerintahan itu dalam menyelenggarakan hak istimewa, dengan maksud mengadakan perubahan dalam lapangan perhubunganperhubungan hukum. 
Berdasarkan beberapa definisi dari para sarjana tersebut, tampak ada beberapa unsur yang terdapat dalam beschikking, yaitu (Ridwan HR, 2011: 143):

1) Pernyataan kehendak sepihak (enjizdige schriftelijke wilsverklaring);

2) Dikeluarkan oleh organ pemerintahan (bestuursorgaan);

3) Didasarkan pada kewenangan hukum yang bersifat publik (publiekbevoegdheid);

4) Ditujukan untuk hal khusus atau peristiwa konkret dan individual;

5) Dengan maksud untuk menimbulkan akibat hukum dalam bidang administrasi.

Dari berbagai definisi tersebut, bahwa beschikking (keputusan), ialah suatu perbuatan hukum publik bersegi satu, yang dilakukan oleh alat pemerintahan (dalam arti sempit) berdasarkan suatu kekuasaan atau wewenang istimewa dengan maksud terjadinya perubahan hubungan hukum (Marbun, 2011: 149).

\section{Asas-Asas dan Norma-Norma HAN dalam Pembuatan Peraturan Perundang-Undangan, Peraturan Kebijakan (Beleidsregel), dan Pembuatan Keputusan}

\section{a. Asas-Asas dan Norma-Norma HAN dalam Pembuatan Peraturan Perundang-Undangan}

Mengacu pada teori negara kesejahteraan (welfare state, verzorgingsstaat), tugas pemerintah tidak hanya terbatas untuk melaksanakan undang-undang yang telah telah dibuat oleh lembaga legislatif. Menurut perspektif welfare state, pemerintah dibebani kewajiban untuk menyelenggarakan kepentingan umum (bestuurszorg) atau mengupayakan kesejahteraan sosial, yang dalam menyelenggarakan kewajiban itu pemerintah diberi kewenangan untuk campur tangan (staatsbemoeienis) dalam kehidupan masyarakat, dalam batas-batas yang diperkenankan oleh hukum. Bersamaan dengan campur tangan tersebut, pemerintah juga diberi kewenangan untuk membuat dan menggunakan peraturan perundang-undangan. Arti lain, pemerintah memiliki kewenangan dalam bidang legislasi (Ridwan HR, 2011: 133).

Konsep pemisahan kekuasaan, khususnya yang berkenaan dengan fungsi eksekutif yang hanya sebagai pelaksana undang-undang tanpa kewenangan membuat peraturan perundang-undangan, seiring dengan perkembangan tugastugas negara dan pemerintahan, bukan saja kehilangan relevansinya, tetapi juga dalam praktek menemui banyak kendala. Karena itu, meskipun ada yang menyatakan bahwa organ legislatif merupakan organ utama pembuatan peraturan perundang-undangan, sedangkan organ eksekutif sebagai organ sekunder dalam pembuatan peraturan perundang-undangan, akan tetapi seperti disebutkan H.W.R. Wade, jika kita hanya mengukur dari segi jumlah, sebagian besar peraturan perundang-undangan dibentuk oleh pemerintah eksekutif daripada oleh legislatif. Meskipun sebagian besar peraturan perundang-undangan itu dibentuk oleh organ eksekutif, namun bukan berarti eksistensi lembaga legislatif dalam suatu negara hukum itu menjadi tidak perlu. Karena itu cukup bijaksana jika dikatakan, “...Perhaps be more realistic to say that the government makes the laws subject to prior 
parliamentary consent". Hal itu karena kewenangan legislasi bagi pemerintah atau organ eksekutif itu pada dasarnya berasal dari undang-undang sesuai dengan asas legalitas dalam negara hukum yang berarti berasal dari persetujuan parlemen (Ridwan HR, 2011: 134).

Pemberian kewenangan legislasi kepada pemerintah itu semakin mendesak sejak berkembangnya ajaran negara kesejahteraan, yang memberikan kewajiban kepada pemerintah untuk memberikan pelayanan sosial dan mewujudkan kesejahteraan umum, yang untuk menopang peranan ini pemerintah dilekati dengan kewenangan legislasi. Artinya tidak mungkin meniadakan kewenangan legislasi bagi pemerintah (Ridwan HR, 2011: 135). Bagir Manan menyebutkan ketidakmungkinan meniadakan kewenangan eksekutif (pemerintah) untuk ikut membentuk peraturan perundang-undangan, sebagai berikut (Manan, 1995: 7-9):

1) Paham pembagian kekuasaan yang lebih menekankan pada perbedaan fungsi daripada pemisahan organ seperti terdapat dalam ajaran pemisahan kekuasaan. Dengan demikian, fungsi pembentukan peraturan perundang-undangan tidak harus terpisah dari fungsi penyelenggaraan pemerintahan. Fungsi pembentukan peraturan perundangan-undangan dapat juga dilekatkan pada administrasi negara, baik sebagai kekuasaan madiri atau sebagai kekuasaan yang dijalankan secara bersama-sama dengan badan legislatif.

2) Paham yang memberikan kekuasaan pada negara atau pemerintahan untuk mencampuri perikehidupan masyarakat, baik sebagai negara kekuasaan atau negara kesejahteraan. Menurut paham negara kekuasaan, ikut campurnya negara atau pemerintah dilakukan dalam rangka membatasi dan mengendalikan rakyat. Salah satu hal yang menunjang secara formal pelaksanaan kekuasaan semacam itu, maka diciptakan berbagai instrumen hukum yang akan memberikan dasar bagi negara atau pemerintah untuk bertindak. Sebagai negara kesejahteraan, diperlukan berbagai instrumen hukum yang tidak mungkin semata-mata diserahkan legislatif. Untuk menyelenggarakan kesejahteraan umum, administrasi negara memerlukan wewenang dalam rangka mengatur tanpa mengabaikan asas-asas negara berdasarkan hukum dan asas-asas umum pemerintah yang baik. Dalam keadaan demikian, makin tumbuh kekuasaan administrasi negara di bidang pembentukan peraturan perundang-undangan.

3) Untuk menunjang perubahan masyarakat yang berjalan makin cepat dan kompleks diperlukan percepatan pembentukan hukum. Hal ini mendorong administrasi negara berperan lebih besar dalam pembentukan peraturan perundang-undangan.

4) Berkembangnya berbagai jenis peraturan perundang-undangan mulai dari UUD sampai pada peraturan perundang-undangan tingkat daerah. Badan legislatif tidak membentuk segala jenis peraturan perundang- 
undangan melainkan terbatas pada undang-undang dan UUD. Jenis-jenis lain dibuat oleh administrasi negara.

Selain itu, terdapat alasan lain diberikannya kewenangan legislasi bagi pemerintah yaitu berkenaan dengan sifat dari norma hukum tata negara dan hukum administrasi negara, yakni bersifat umum-abstrak (algemeen-abstract). Ketika menghadapi peristiwa konkret, norma yang bersifat umum-abstrak tersebut membutuhkan instrumen yuridis yang bersifat konkret-individual (Ridwan HR, 2011: 136). Oleh karena itu, dalam kepustakaan hukum administrasi negara terdapat istilah langkah mundur pembuat undang-undang (terugtred van de wetgever). Sikap mundur ini diambil dalam upaya mengaplikasikan norma hukum administrasi negara yang bersifat umum-abstrak terhadap peristiwa konkret dan individual. Dalam hal ini A.D. Belinfante mengatakan sebagai berikut (Ridwan HR, 2011: 137):

"De wet geeft daan aan een bestuurlijk orgaan de bevougdheid door administratiefrechtelijke rechtshandelingen rechtsbetrekkingen tusssen dat orgaan en burgers te scheppen. De terugtred is onvermijdelijk. Zij biedt het voordeel van neel verder gaande differentiatie naar bijzonderheden van de concrete toestand dan de wetgever ooit zou kunnen bereiken."

(undang-undang memberikan wewenang kepada organ pemerintahan untuk membuat peraturan hukum yang bersifat administrasi dalam rangka hubungan hukum dengan warga negara. Langkah mundur ini tidak dapat dihindarkan, dan akan memberikan keuntungan yang lebih besar untuk waktu yang tidak terbatas yang dapat dijangkau oleh pembuat undangundang)

Menurut Indroharto, manfaat dari sikap mundur pembuat undang-undang seperti ini adalah bahwa penentuan dan penetapan norma-norma hukum oleh badan atau jabatan TUN akan dapat dilakukan diferensiasi menurut keadaan khusus dan konkret dalam masyarakat. Terhadap langkah mundur ini ada tiga sebab, yaitu (Ridwan HR, 2011: 137):

1) Karena keseluruhan hukum tata usaha negara (TUN) itu demikian luasnya, sehingga tidak mungkin bagi pembuat undang-undang untuk mengatur seluruhnya dalam undang-undang formal;

2) Norma-norma hukum TUN itu harus selalu disesuaikan dengan tiap perubahan-perubahan keadaan yang terjadi sehubungan dengan kemajuan dan perkembangan teknologi yang tidak mungkin selalu diikuti oleh pembuat undang-undang dengan mengaturnya dalam suatu UU formal;

3) Selain itu, tiap kali diperlukan pengaturan lebih lanjut hal itu selalu berkaitan dengan penilaian-penilaian dari segi teknis yang sangat mendetail, sehingga tidak sewajarnya harus diminta pembuat undangundang yang harus mengaturnya. 


\section{b. Asas-Asas dan Norma-Norma HAN dalam Pembuatan Peraturan Kebijakan (Beleidsregel)}

Pelaksanaan pemerintahan sehari-hari menunjukan betapa badan atau pejabat tata usaha negara acapkali menempuh pelbagai langkah kebijaksanaan tertentu, antara lain menciptakan apa yang kini sering dinamakan peraturan kebijaksanaan (beleidsregel). Produk semacam peraturan kebijaksanaan ini tidak lepas dari kaitan penggunaan freies Ermessen, yaitu badan atau pejabat tata usaha negara yang bersangkutan merumuskan kebijaksanaannya itu dalam pelbagai bentuk "juridische regels", seperti halnya, peraturan, pedoman, pengumuman, surat edaran,kemudian mengumumkan kebijaksanaan itu.

Kebijaksanaan atau freies Ermessen dapat didefinisikan atau dirumuskan sebagai (Marbun, 2011: 196):

“Kebebasan atau keleluasaan bertindak atas inisiatif sendiri (kebijaksanaan) yang dimungkinkan oleh hukum, untuk menyelesaikan persoalan-persoalan penting yang mendesak yang muncul secara tiba-tiba, yang pengaturannya belum ada atau kewenangannya yang tidak jelas atau samar-samar, yang harus dapat dipertanggungjawabkan baik secara hukum maupun moral."

Definisi kebijaksanaan tersebut di atas menurut SF Marbun terdiri dari unsurunsur sebagai berikut (Marbun, 2011: 196-202):

1) Adanya kebebasan yang dimungkinkan oleh hukum kepada administrasi negara untuk bertindak atas inisiatif sendiri.

2) Terdapatnya persoalan penting dan mendesak untuk segera diselesaikan

3) Harus dapat dipertanggungjawabkan secara moral dan hukum

Sebagaimana pembuatan dan penerapan peraturan perundang-undangan, yaitu harus memerhatikan beberapa persyaratan, pembuatan dan penerapan peraturan kebijakan juga harus memerhatikan beberapa persyaratan. Menurut Indroharto yang dikutip oleh Ridwan, pembuatan peraturan kebijakan harus memperhatikan hal-hal sebagai berikut (Ridwan HR, 2011: 183-184):

1) Ia tidak boleh bertentangan dengan peraturan dasar yang mengandung wewenang diskresioner yang dijabarkan itu;

2) Ia tidak boleh nyata-nyata bertentangan dengan nalar yang sehat;

3) Ia harus dipersiapkan dengan cermat, semua kepentingan, keadaankeadaan serta alternatif-alternatif yang ada perlu dipertimbangkan;

4) Isi dari kebijakan harus memberikan kejelasan yang cukup mengenai hak-hak dan kewajiban-kewajiban dari warga yang terkena peraturan tersebut;

5) Tujuan-tujuan dan dasar-dasar pertimbangan mengenai kebijakan yang akan ditempuh harus jelas;

6) Ia harus memenuhi syarat kepastian hukum materiil, artinya hak-hak yang telah diperoleh dari warga msayarakat yang terkena harus 
dihormati, kemudian juga harapan-harapan warga yang pantas telah ditimbulkan jangan sampai diingkari.

Sedangkan dalam penerapan atau penggunaan peraturan kebijakan harus memerhatikan hal-hal sebagai berikut (Ridwan HR, 2011: 184):

1) Harus sesuai dan serasi dengan tujuan undang-undang yang memberikan beoordelingsvrijheid (ruang kebebasan bertindak);

2) Serasi dengan asas-asas hukum umum yang berlaku, seperti:

a) Asas perlakukan yang sama menurut hukum;

b) Asas kepatutan dan kewajaran;

c) Asas keseimbangan;

d) Asas pemenuhan kebutuhan dan harapan; dan

e) Asas kelayakan mempertimbangkan segala sesuatu yang relevan dengan kepentingan publik dan warga masyarakat.

3) Serasi dan tepatguna dengan tujuan yang hendak dicapai.

Peraturan kebijakan sesuai dengan kemunculannya bukan berasal dari kewenangan pembuatan peraturan perundang-undangan (wetgevende bevoegdheid), karena itu tidak dapat diuji dengan mendasarkan pada aspek rechtmatigheid. Berdasarkan hukum administrasi negara, pengujian peraturan kebijakan adalah aspek doelmatigheid dengan menggunakan asas-asas umum pemerintahan yang baik (AAUPB), khususnya asas larangan penyalahgunaan wewenang (detournement de pouvoir) dan asas larangan sewenang-wenang (willekeur). Maksud lainnya, kebijakan pemerintah akan dikategorikan sebagai kebijakan yang menyimpang jika di dalamnya ada unsur penyalahgunaan wewenang dan unsur sewenang-wenang (Ridwan HR, 2011: 185).

\section{c. Asas-Asas dan Norma-Norma HAN Dalam Pembuatan Keputusan}

Pengertian keputusan menurut Pasal 1 angka 3 UU No.5 Tahun 1986 jo Pasal 1 angka 9 UU No. 5 Tahun 2009 tentang Perubahan Kedua Atas UU No.5 Tahun 1986 tentang PTUN ialah(SF Marbun, 2011: 162):

"Suatu penetapan tertulis, yang dikeluarkan oleh Badan atau Pejabat Tata Usaha Negara, yang berisi tindakan hukum tata usaha negara, yang berdasarkan peraturan perundang-undangan yang berlaku, yang bersifat konkret, individual, dan final, yang menimbulkan akibat hukum bagi seseorang atau Badan Hukum Perdata."

Mengacu pada rumusan pengertian keputusan tersebut di atas, dapat ditarik unsur-unsur yuridis keputusan menurut hukum positif sebagai berikut (Marbun, 1987: 10):

1) Suatu penetapan tertulis;

2) Dikeluarkan oleh badan atau pejabat tata usaha negara;

3) Berisi tindakan hukum tata usaha negara;

4) Berdasarkan peraturan perundang-undangan yang berlaku;

5) Bersifat konkrit, individual dan final;

6) Menimbulkan akibat hukum bagi seseorang atau badan hukum perdata. 
Pembuatan keputusan tata usaha negara harus memerhatikan beberapa persyaratan agar keputusan tersebut menjadi sah menurut hukum (rechtsgeldig) dan memiliki kekuatan hukum (rechtskracht) untuk dilaksanakan. Syarat-syarat yang harus diperhatikan dalam pembuatan keputusan ini mencakup syarat materiil dan syarat formal, yaitu (Ridwan HR, 2011: 162):

1) Syarat-syarat materiil yang terdiri dari:

a) Organ pemerintahan yang membuat keputusan harus berwenang;

b) Karena keputusan suatu pernyataan kehendak (wilsverklaring), maka keputusan tidak boleh mengandung kekurangan-kekurangan yuridis (geen juridische gebreken in dewilsvorming), seperti penipuan (bedrog), paksaan (dwang) atau suap (omkoping), kesesatan (dwaling);

c) Keputusan harus berdasarkan suatu keadaan (situasi) tertentu;

d) Keputusan harus dapat dilaksanakan dan tanpa melanggar peraturan-peraturan lain, serta isi dan tujuan keputusan itu harus sesuai dengan isi dan tujuan peraturan dasarnya.

2) Syarat-syarat formal yang terdiri atas:

a) Syarat-syarat yang ditentukan berhubung dengan persiapan dibuatnya keputusan dan berhubung dengan cara dibuatnya keputusan harus dipenuhi;

b) Keputusan harus diberi bentuk yang telah ditentukan dalam peraturan perundang-undangan yang menjadi dasar dikeluarkannya keputusan itu;

c) Syarat-syarat berhubung dengan pelaksanaan keputusan itu harus dipenuhi;

d) Jangka waktu harus ditentukan antara timbulnya hal-hal yang menyebabkan dibuatnya dan diumumkannya keputusan itu harus diperhatikan.

Apabila syarat materiil dan syarat formal ini telah terpenuhi, maka keputusan itu sah menurut hukum (rechtsgeldig), artinya dapat diterima sebagai suatu bagian dari tertib hukum atau sejalan dengan ketentuan hukum yang ada baik secara prosedural/formal maupun materiil (Ridwan HR, 2011: 163).

Keputusan yang sah dan sudah dinyatakan berlaku, di samping mempunyai kekuatan hukum formal materiil, juga akan melahirkan prinsip praduga rechtmatig (het vermoeden van rechtmatigheid atau presumtio justea causa). Prinsip ini mengandung arti bahwa "setiap keputusan yang dikeluarkan oleh pemerintah atau administrasi negara itu dianggap sah menurut hukum". Asas praduga rechtmatigini membawa konsekuensi bahwa setiap keputusan yang dikeluarkan oleh pemerintah tidak untuk dicabut kembali, kecuali setelah ada pembatalan (vernietiging) dari pengadilan. Lebih lanjut, konsekuensi praduga rechtmatig ini adalah bahwa pada dasarnya keputusan yang telah dikeluarkan oleh pemerintah itu tidak dapat ditunda pelaksanaannya meskipun terdapat keberatan (bezwaar), banding (beroep), 
perlawanan (bestreden), atau gugatan terhadap suatu keputusan oleh pihak yang dikenai keputusan tersebut (Ridwan HR, 2011: 166-167).

\section{PENUTUP \\ 1. KESIMPULAN}

Peraturan adalah hukum yang in abstracto atau general norm yang sifatnya mengikat umum (berlaku umum) dan tugasnya adalah mengatur hal-hal yang bersifat umum (general). Berdasarkan penjelasan Pasal 1 angka 2 UU No.5 Tahun 1986 tentang Peradilan Tata Usaha Negara, peraturan perundang-undangan adalah semua peraturan yang bersifat mengikat secara umum yang dikeluarkan oleh Badan Perwakilan Rakyat bersama pemerintah baik di tingkat pusat maupun daerah, serta semua keputusan badan atau pejabat tata usaha negara, baik di tingkat pusat, maupun di daerah, yang juga mengikat umum.

Peraturan perundang-undangan memiliki ciri-ciri sebagai berikut:

a. Bersifat umum dan komprehensif, yang dengan demikian merupakan kebalikan dari sifat-sifat yang khusus dan terbatas.

b. Bersifat universal. Ia diciptakan untuk menghadapi peristiwa-peristiwa yang akan datang yang belum jelas bentuk konkretnya. Oleh karena itu, ia tidak dapat dirumuskan untuk mengatasi peristiwa-peristiwa tertentu saja.

c. Ia memiliki kekuatan untuk mengoreksi dan memperbaiki dirinya sendiri. Adalah lazimnya bagi suatu peraturan untuk mencantumkan klausul yang memuat kemungkinan dilakukannya peninjauan kembali.

Peraturan kebijakan hanya berfungsi sebagai bagian dari operasional penyelenggaraan tugas-tugas pemerintahan, karenanya tidak dapat mengubah ataupun menyimpangi peraturan perundang-undangan. Peraturan ini adalah semacam hukum bayangan dari undang-undang atau hukum. Oleh karena itu, peraturan ini disebut pula dengan istilah psudo wetgeving (perundang-undangan semu) atau spigelsrecht (hukum bayangan/cermin). Secara praktis kewenangan diskresioner administrasi negara yang kemudian melahirkan peraturan kebijakan, mengandung dua aspek pokok; Pertama, kebebasan menafsirkan mengenai ruang lingkup wewenang yang dirumuskan dalam peraturan dasar wewenangnya. Aspek pertama ini lazim dikenal dengan kebebasan menilai yang bersifat objektif. Kedua, kebebasan untuk menentukan sendiri dengan cara bagaimana dan kapan wewenang yang dimilki administrasi negara itu dilaksanakan.

Berkenaan dengan Keputusan (beschikking), meskipun diasumsikan bahwa setiap keputusan yang telah dikeluarkan dianggap sah oleh hukum, akan tetapi di dalam praktek hampir semua surat keputusan, khususnya dalam praktek administrasi negara di Indonesia, terdapat klausula pengaman (veiligheidsclausule) yang pada umum berbunyi; "Apabila di kemudian hari terdapat kekeliruan atau kekurangan, maka surat keputusan ini akan ditinjau kembali”. Rumusan seperti itu di satu sisi bertentangan dengan asas kepastian hukum dan di sisi lain bertentangan dengan asas praduga rechtmatig. Dengan kata lain, klausul pengaman itu merupakan 
sesuatu hal yang keliru, tidak bermanfaat dan mubazir, sebab dapat menggoyahkan sendi-sendi kepastian hukum.

\section{SARAN}

Dari berbagai permasalahan yang diuraikan, penulis memberikan saran, demi menjaga kepastian hukum, dan demi menjaga kemaslahatan hukum, maka pemerintah dalam hal membuat peraturan perundang-undangan maupun keputusan harus berlandaskan asas-asas yang tertuang di dalam Hukum Administrasi Negara, sehingga diskresi yang akan muncul di kemudian hari dapat dihindarkan.

\section{DAFTAR PUSTAKA}

\section{A. BUKU, JURNAL DAN MAKALAH}

Attamimi, A Hamid S (1992). Perbedaan antara Peraturan Perundang-undangan dan Peraturan Kebijakan, Makalah pada Pidato Dies Natalis PTIK Ke-46. Jakarta.

Hadjon, M Philipus dkk (1999). Pengantar Hukum Administrasi Indonesia (Introduction to the Indonesian Administrative Law). Yogyakarta: Gadjah Mada University Press.

HR, Ridwan (2011). Hukum Administrasi Negara(Edisi Revisi). Jakarta: Raja Grafindo Persada.

Koesoemahatmadja, Djenal Hoesen (1979). Pokok-Pokok Hukum Tata Usaha Negara. Alumni: Bandung.

Luqman, Marcus (1989). Freies Ermessen dalam Proses dan Pelaksanaan Rencana Kota. Tesis UNPAD.

Marbun, SF (1987). Telaah Yurisprudensi Aaanwijziq Natuurmonumenten, Penunjukan Satu Daerah Sebagai Staatnatuurmonument Bukan Merupakan Keputusan yang Mengikat Umum. paper untuk Penataran Hukum Administrasi Negara. Kerjasama Indonesia - Belanda, UNPAD. Bandung.

Marbun, SF dan Mahfud MD, Moh (2006). Pokok-Pokok Hukum Administrasi Negara. Yogyakarta: Liberty.

(2011). Peradilan Administrasi Negara dan Upaya Administratif di Indonesia.Yogyakarta: FH UII Press.

Manan, Bagir (1995). Peranan Hukum Administrasi Negara dalam Pembentukan Peraturan Perundang-undangan. Makalah disampaikan pada Penataran Nasional Hukum Administrasi Negara. Fakultas Hukum UnhasUjung Pandang.

Muslimin, Amrah (1985). Beberapa Asas dan Pengertian Pokok-Pokok tentang Administrasi dan Hukum Administrasi. Bandung: Alumni.

Smith, Stanley De and Brazier, Rodney (1986). Constitutional and Administrative Law. Penguin Book.

\section{B. PERATURAN PERUNDANG-UNDANGAN:}

UUD NRI 1945 


\section{NOVEELTYY}

UU NO. 5 Tahun 1986 tentang Peradilan Tata Usaha Negara

UU No.5 Tahun 1986 jo Pasal 1 angka 9 UU No. 5 Tahun 2009 tentang Perubahan Kedua Atas UU No.5 Tahun 1986 tentang PTUN

UU No. 10 Tahun 2004 Tentang Pembentukan Peraturan Perundang-undangan 